\title{
Water Hyacinth as Indicator of Heavy Metal Pollution in the Tropics.
}

\section{Gonzalez, H.}

Springer-Verlag New York Inc.

1989

Gonzalez, H. et al. 1989. Water Hyacinth as Indicator of Heavy Metal Pollution in the Tropics. Bulletin of Environmental Contamination and Toxicology 43: 910-914.

http://hdl.handle.net/1975/192

Downloaded from Helda, University of Helsinki institutional repository.

This is an electronic reprint of the original article.

This reprint may differ from the original in pagination and typographic detail.

Please cite the original version. 


\title{
Water Hyacinth as Indicator of Heavy Metal Pollution in the Tropics
}

\author{
Humberto Gonzalez, ${ }^{1}$ Martin Lodenius, ${ }^{2}$ and Mirta Otero' \\ 1/nstitute of Transport Investigations, Casablanca, Havana, Cuba and \\ 2Department of Environmental Conservation, University of Helsinki, \\ SF-00710 Helsinki, Finland
}

The water hyacinth (Eichhomia crassipes) is a common aquatic plant in many tropical countries. Its ability to absorb nutrients and other elements from the water has made it possible to use it for water purification purposes (e.g. Chigbo et al. 1982, Muramoto and Oki 1983). Eichhomia, especially stems and leaves, have been successfully used as indicators of heavy metal pollution in tropical countries (Ajmal et al. 1985, Pfeiffer et al. 1986). The uptake of heavy metals in this plant is stronger in the roots than in the floating shoots (Jana 1988). Metallothionein-like compounds have been found from roots of this species after cadmium exposure (Fujita 1985). The purpose of this investigation was to study the possibilities of using roots of water hyacinth as a biological indicator of metal pollution in tropical aquatic ecosystems.

\section{MATERIAL AND METHODS}

The basin of the river Sagua la Grande covers $2,170 \mathrm{~km}^{2}$ and the length of the river is $163 \mathrm{~km}$. However, the sampling sites of this study extended for only 25 - 30 km (Fig. 1). The city of Sagua la Grande has approximately 60,000 inhabitants, a chlor-alkali plant, a smelter and minor industrial plants. According to a study by Gonzalez and Lera (1987) on river sediments the city pollutes the river with $\mathrm{Pb}, \mathrm{Zn}$, $\mathrm{Cu}$ and $\mathrm{Cd}$ but not with $\mathrm{Cr}$ or $\mathrm{Ni}$.

Samples were taken six times during the years 1985 to 1988 (Table 1) in the river Sagua la Grande, central Cuba. For different reasons (occurrence of water hyacinth, water level, etc), it was not possible to collect samples from all sites at all times. Reference samples were collected from the river San Juan (Matanzas; SJ1 and SJ2 in Table 1), from the dam Alacranes (Villa Clara; P10) and from the lagoon Segundo Frente (Santiago de Cuba; L17).

Roots of water hyacinth were collected by hand, rinsed with river water, packed in nylon bags and transported to the laboratory where they were washed with tap and twice distilled water. The samples were dried at $45^{\circ} \mathrm{C}$ (the samples were also used for $\mathrm{Hg}$ analyses) and cut with stainless steel scissors. One gram of the sample $(2 \mathrm{~g}$ in March 1987) was digested in concentrated $\mathrm{HNO}_{3} / \mathrm{HClO}_{4}$. The metal contents were determined by flame atomic absorption spectrometry with background correction (SATURN 2). The accuracy of this method for biological materials was tested in an international intercalibration (lab 50A in Anonymous 1987) using IAEA reference materials. 


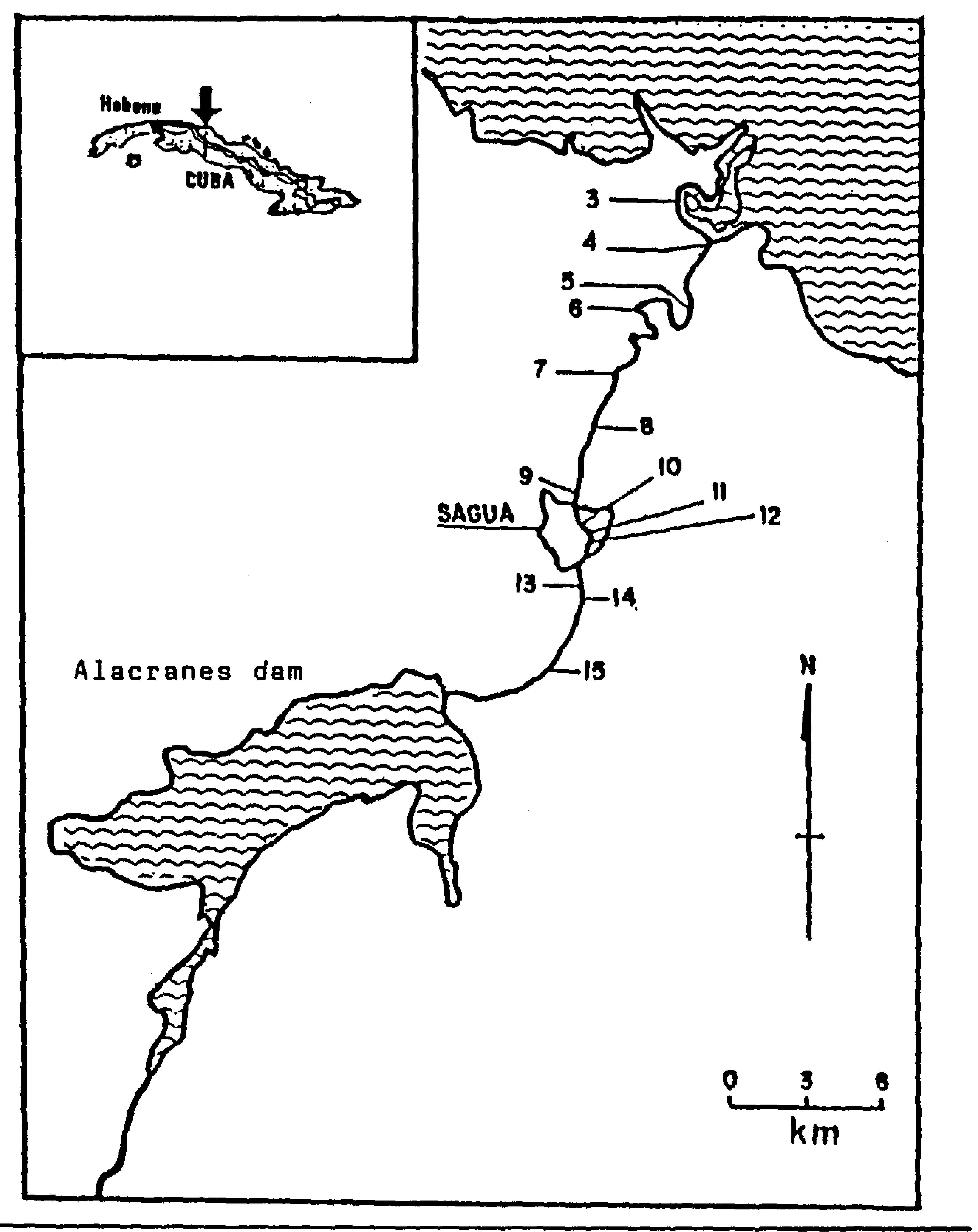

Figure 1. The study area.

\section{RESULTS AND DISCUSSION}

The lowest concentrations of metals were found in water hyacinths taken upstream from the city of Sagua (sites 15 - 13), which are considered less polluted (Table 1). Highest concentrations were found in the zone situating near Sagua city (sites 129) which receives urban and industrial effluents. In the river downstream from the city (sites 8 - 3), levels of metal in hyacinth root were lower than within the city but indicated still influence of pollution from the city. 


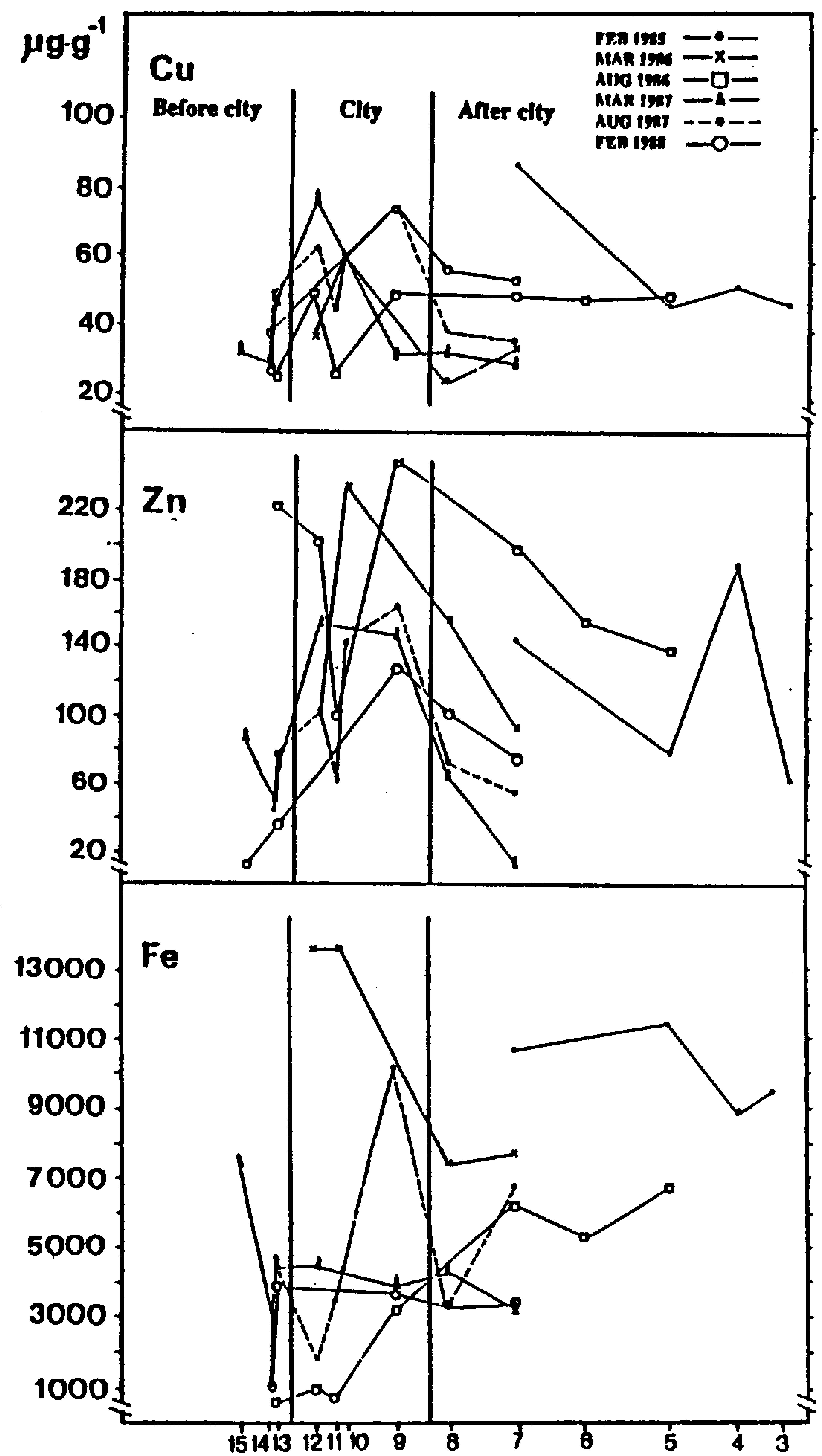

Figure 2 Levels of metals in Eichhomia crassipes roots along the River Sagua la Grande. The numbers of the sampling sites refer to Fig. 1. 
Table 2. Levels of metals ( $\mathrm{mg} \mathrm{kg}^{-1} \mathrm{dry} w$ ) of roots of Eichhomia crassipes collected from three zones of River Sagua and from reference sites.

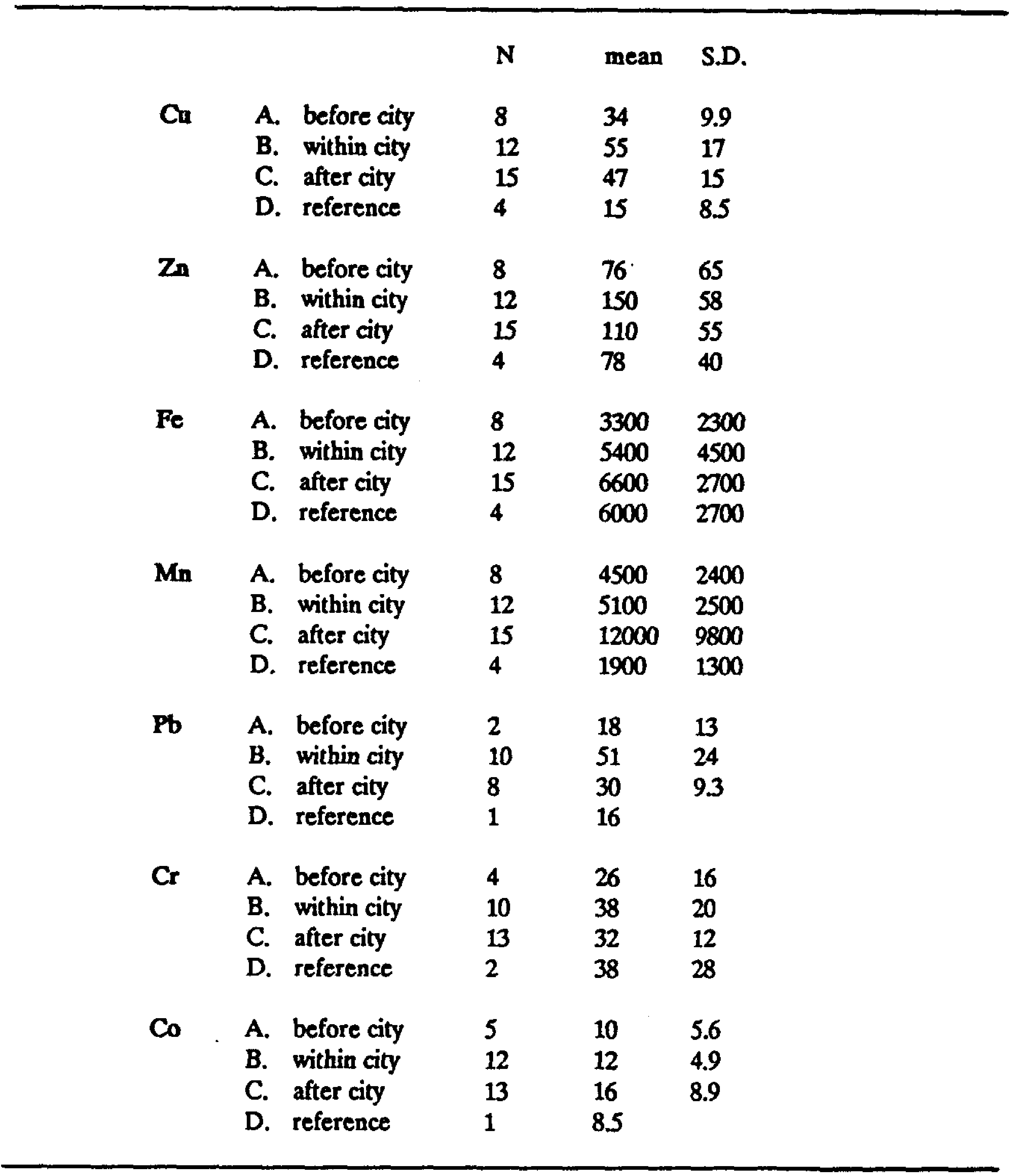

It was not always possible to collect samples from all sites, but we normally analyzed samples from all three zones. The fluctuations of $\mathrm{Cu}, \mathrm{Zn}$ and $\mathrm{Fe}$ are presented in Fig. 2. Despite considerable temporal variations there is a clear increase in metal levels of Eichhomia roots starting from the city downstream. In general, there were significant differences between the values above and within or below the city (Table 3). This - was also true for $\mathrm{Mn}$ which has not been considered a good indicator of urban effluents. The differences in iron contents are less distinct, which possibly indicates that iron would not be as good an indicator of urban effluents as e.g. copper and zinc (cf. Salomons and Förstner 1984). The variations between sampling periods and sampling sites may be explained by the numerous factors affecting the uptake of metals by water hyacinth (discharges, water volume, etc.). Also the age of the water hyacinth may affect the concentrations.

The samples collected from polluted and unpolluted areas show the ability of Eichhomia crassipes to accumulate heavy metals in the root and serve as a bioindicator of metal pollution. 
Table 3. Percent probability of differences between groups (ANOVA) for four metals. $A=$ Before city, $B=$ Within city, $C=$ After city, $D=$ Reference sites.

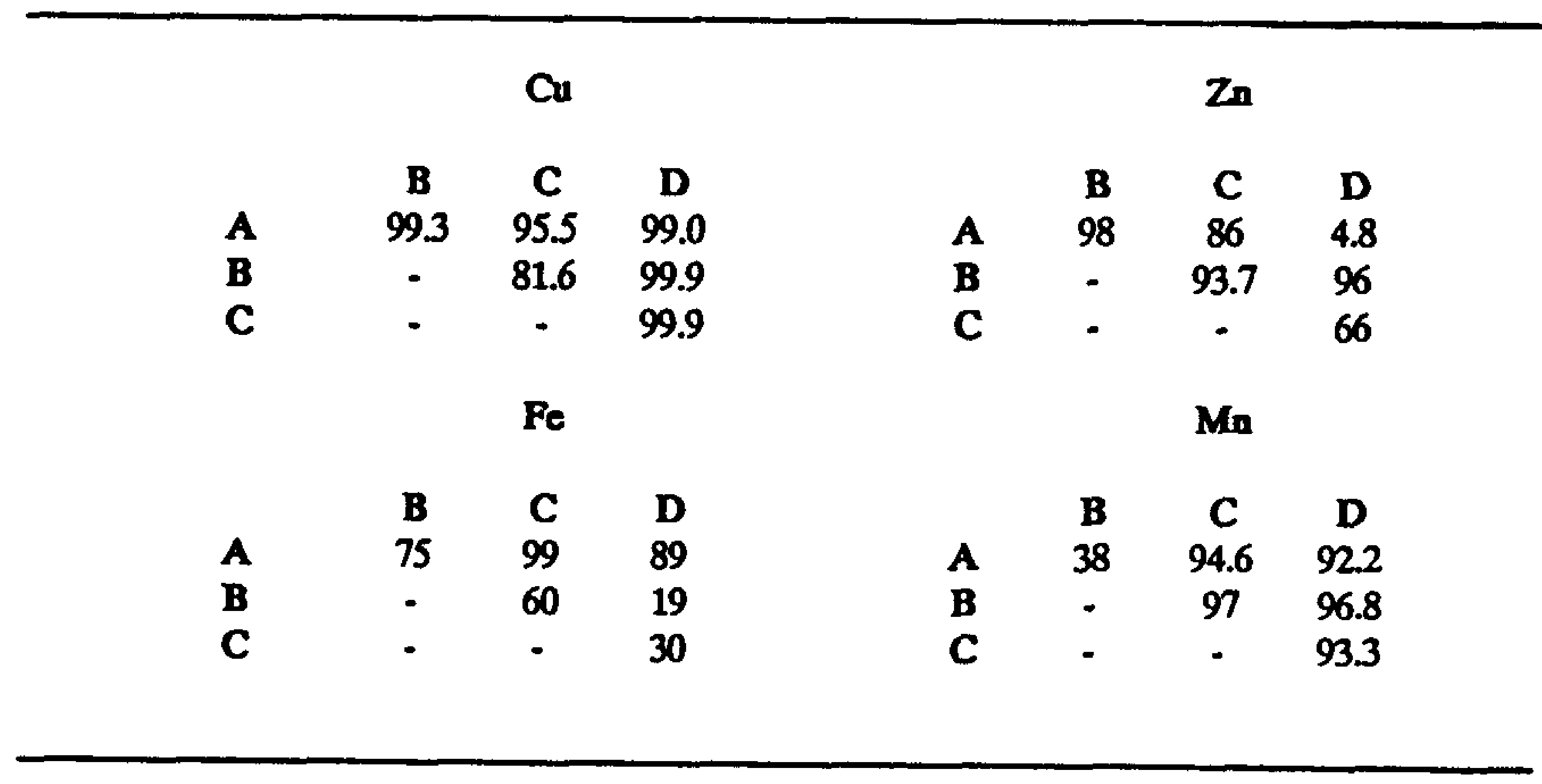

\section{REFERENCES}

Ajmal M, Khan MA \& Nomani AA (1985) Distribution of heavy metals in plants and fish of the Yamuna river (India). Environ Monit Assessm 5:361-367.

Anonymous (1987) Intercalibration of analytical methods on marine environmental samples. IAEA \& UNEP, Progress Rep 34.

Chigbo FE, Smith RW \& Shore FL (1982) Uptake of arsenic, cadmium, lead and mercury from polluted waters by the water hyacinth Eichhomia crassipes. Environ Pollut A27:31-36.

Fujita M (1985) The presence of two Cd-binding components in the roots of water hyacinth cultivated in a $\mathrm{Cd}^{2+}$-containing medium. Plant Cell Physiol 26:295-300.

Gonzalez H \& Lera L (1987) Metales pesados en sedimentos del rio Sagua y la bahia de Isabela. Memorias XII Conf Quimica, Univ Oriente IV:129-135.

Jana $S$ (1988) Accumulation of $\mathrm{Hg}_{\mathrm{g}}$ and $\mathrm{Cr}$ by three aquatic species and subsequent changes in several physiological and biochemical parameters. Water Air Soil Pollut 38:105-109.

Muramoto S \& Oki Y (1983) Removal of some heavy metals from polluted water by water hyacinth. Bull Environ Contam Toxicol 30:170-177.

Pfeiffer WC, Fiszman M, Malm O \& Azcue JM (1986) Heavy metal pollution in the Paraibo do Sul river, Brazil. Sci Total Environ 58:73-79.

Salomons W \& Förstner U (1984) Metals in the hydrocycle. Springer, Berlin. 349 pp.

Received June 5, 1989; accepted June 20, 1989. 